EDrToR's Note:

This article is intended for those persons who wish to study in some detail how the volume of money in the U.S. economy is determined. Examples of ways the money stock is influenced by factors other than actions of the monetary authority are illustrated in two ways-changes in components of the "monetary multiplier" and changes in entries in "T-Accounts" or commercial bank balance sheets.

\title{
Elements of Money Stock Determination
}

\author{
By JERRY L. JORDAN
}

\begin{abstract}
$\mathrm{R}$ ECENT DISCUSSION of the role of money in stabilization policy has culminated in two central issues. The first involves the strength and reliability of the relation between changes in money and changes in total spending. If this relation is sufficiently strong and reliable, changes in the money stock can be used as an indicator of the influence of monetary stabilization actions on the economy. ${ }^{1}$ The second issue centers on whether or not the monetary authorities can determine the growth of the money stock with sufficient precision, if it is deemed desirable to do so.
\end{abstract}

This article is concerned primarily with the second issue-determination of the money stock. ${ }^{2}$ A framework describing the factors which influence the monetary authorities' ability to determine the money stock is presented, and the behavior of these factors in recent years is illustrated. In addition, examples of ways in which these factors influence the money stock are discussed.

\section{Factors Influencing the Money Stock}

The following sections present essential elements and concepts which are used to construct a "money supply model" for the U.S. economy. First, the necessary information regarding institutional aspects of the U.S. banking system are summarized. Then,

\footnotetext{
1.Leonall C. Andersen and Jerry L. Jordan, "Monetary and Fiscal Actions: A Test of Their Relative Importance in Economic Stabilization," this Review, Novenber 1968.

2Private demand deposits plus currency in the hands of the public.
}

the main elements of the model - the monetary base, the member bank reserve-to-deposit ratio, the currency-to-demand deposit ratio, the time deposit-todemand deposit ratio, and the U.S. Government deposit-to-demand deposit ratio-are discussed.

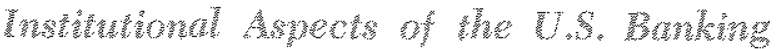 Sycten}

Students of money and banking are taught that if commercial bank reserve requirements are less than 100 per cent, the reserves of the banking system can support a "multiple" of deposits. In fact it is ofte" said that under a fractional reserve system the banking system "creates" deposits. The familiar textbook exposition tells us that the amount of deposits (D) in the system is equal to the reciprocal of the reserve requirement ratio ( $r$ ) times the amount of reserves (R):

$$
\mathrm{D}=\frac{1}{\mathrm{r}} \cdot \mathrm{R}
$$

Thus if the banking system has $\$ 100$ of reserves, and the reserve requirement ratio is 20 per cent (.2), deposits will be $\$ 100 / .2$ or $\$ 500$. If the banks acquire an additional $\$ 1$ in reserves (for instance from the Federal Reserve), deposits will increase by $\$ 5$.

There are many simplifying assumptions underlying this elementary deposit-expansion relation. First, it is assumed that all bank deposits are subject to the same reserve requirement. Second, all banks are subject to the same regulations; in other words, all banks are members of the Federal Reserve System, and the Federal Reserve does not differentiate among classes of banks. Third, banks do not hold excess 


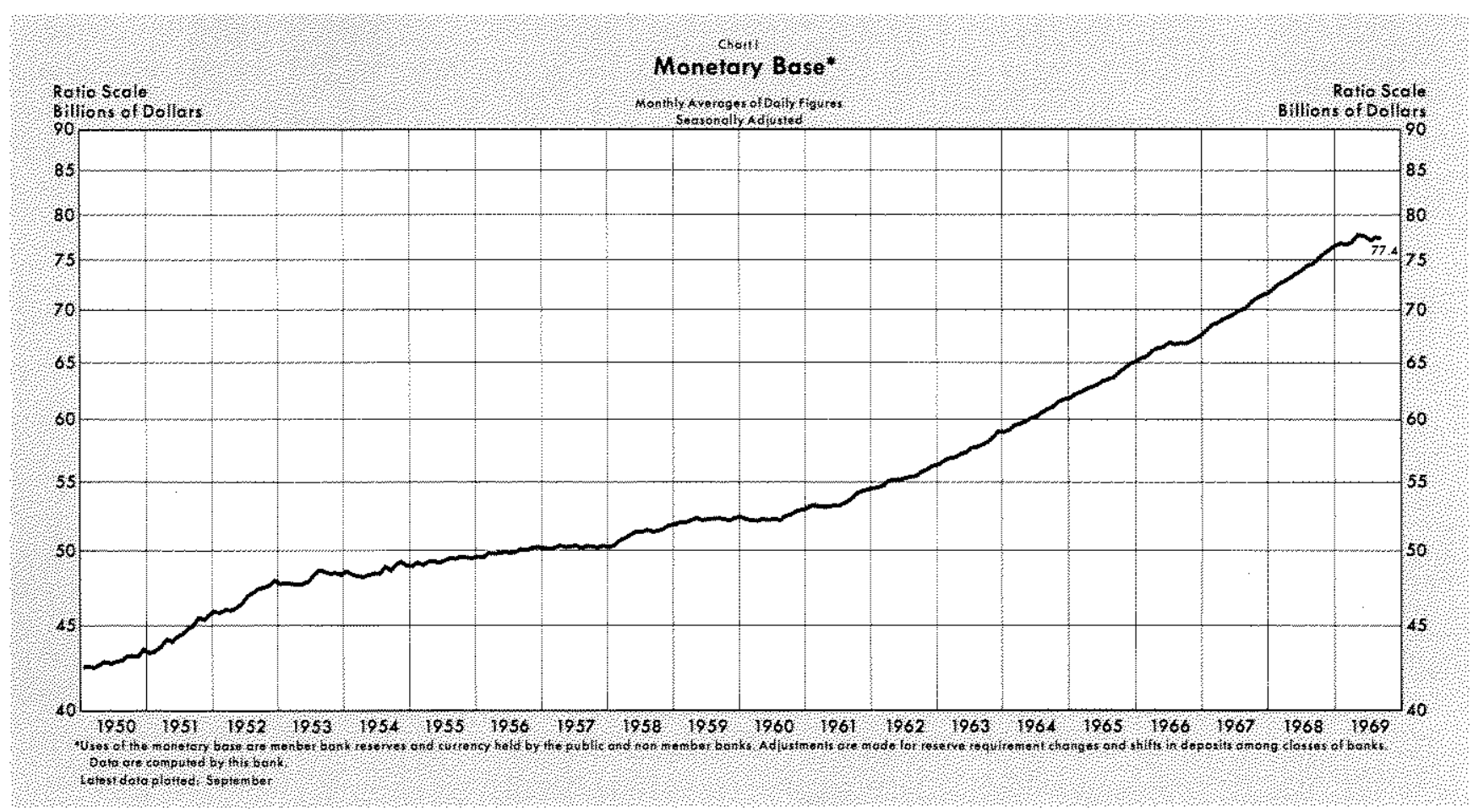

reserves; they are always "loaned up". And finally, there is no "cash drain". The public desires to hold a fixed quantity of currency, and their desires for currency are not influenced by the existence of more or less deposits.

Since the above assumptions are not true, the accuracy with which a monetary analyst can estimate how many deposits will be "created" by an addition of $\$ 1$ in reserves to the banking system, depends on his ability to determine:

(1) how the deposits will be distributed between member and nonmember banks;

(2) how the deposits will be distributed between reserve city and country banks, which are subject to different reserve requirements;

(3) how the deposits will be distributed among private demand deposits, Government demand deposits, and the sub-classes of time deposits, all of which are subject to different reserve requirements;

(4) how the change in deposits will affect banks' desired ratio of excess reserves to total deposits; and

(5) how a change in deposits will affect the public's desired ratio of currency to demand deposits.

These questions can be answered best within the context of a "money supply model" which is con- structed to include the institutional realities of the U.S. banking system, and which does not require the special assumptions of the simple deposit expansion equation. A thoroughly developed and tested money supply model has been advanced by Professors Brunner and Meltzer. ${ }^{3}$ The following sections present the general form and essential features of this model.

\section{Whe Monewary}

A useful concept for monetary analysis is provided by the "monetary base" or "high-powered money"." The monetary base is defined as the net monetary liabilities of the Government (U.S. Treasury and Federal Reserve System) held by the public (commercial banks and nonbank public). More specifically, the monetary base is derived from a consolidated balance sheet of the Treasury and Federal Reserve "monetary" accounts. This consolidated monetary base balance sheet is illustrated in Table I, and monthly data for the monetary base (B) are shown in Chart I.

The growth of the monetary base, that is, "base money," is determined primarily by Federal Reserve

3Karl Brumer and Allan Meltzer, "Liquidity Traps for Money, Bank Credit, and Interest Rates," Journal of Political Economy, Vol. 76, Jantary/February 1968. Also see Albert E. Burger, An Analusis of the Brtanner-Meltzer Non-Linear Money Supply Hypothesis, Working Paper No. 7, Federal Reserve Bank of St. Louis, May 1969.

${ }^{4}$ For further discussion of this concept, see Leonall C. Andersen and Jerry L. Jordan, "The Monetary Base: Explanation and Analytical Use," this Review, August 1968. 


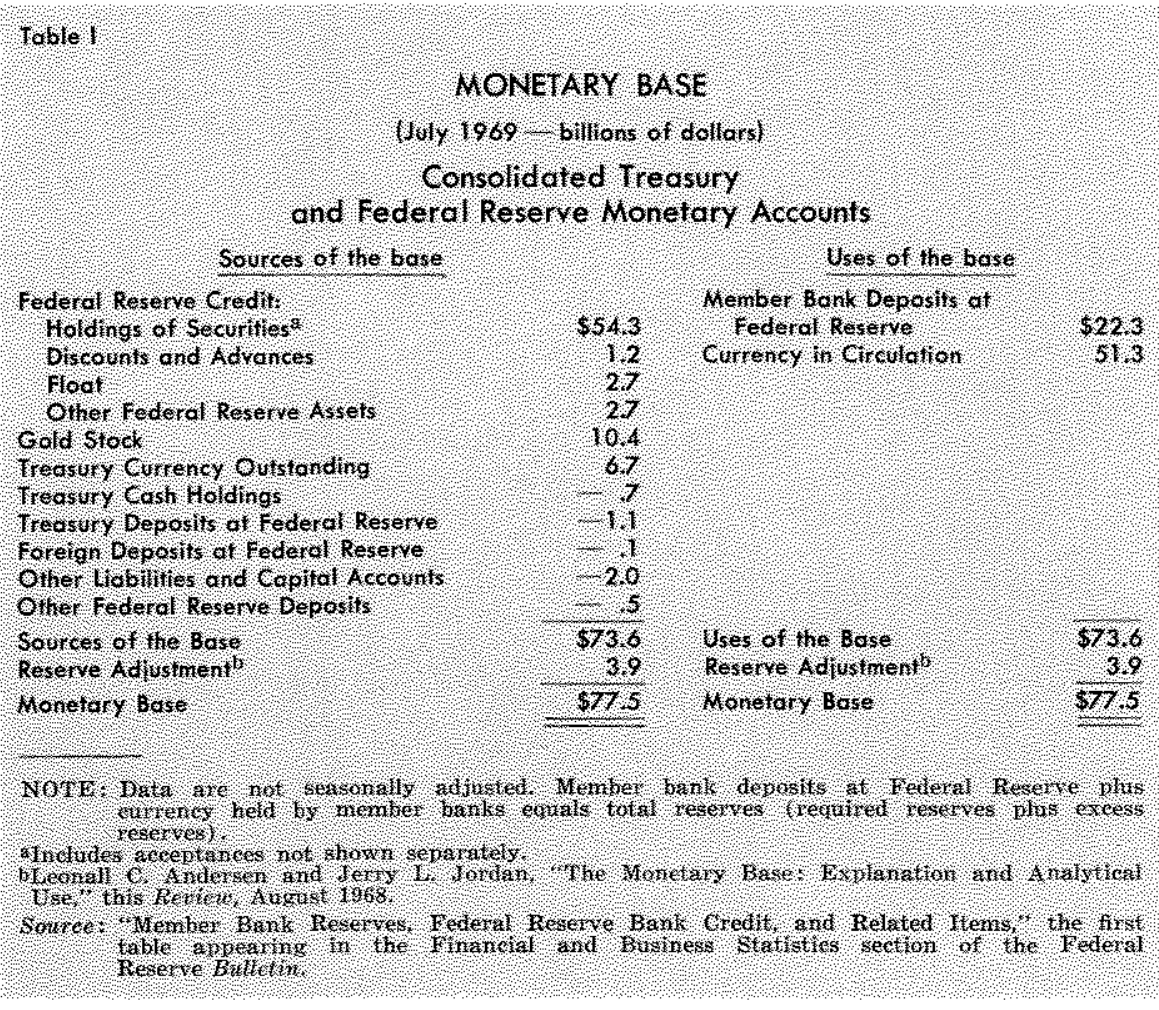

currency held by the nonbank public plus reserves of all commercial banks, shown in Table II below.

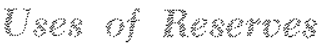

As noted above, analysis of the U.S. monetary system is complicated by the existence of both member and nonmember banks, different classes of member banks, different reserve requirements on different types of deposits (private demand, Government demand, and time), and graduated reserve requirements for different amounts of deposits. It is thus necessary to allocate the uses of bank reserves among the different types of deposits. This is illustrated by an equation showing total bank reserves ( $R$ ) in terms of their uses: holdings of U.S. Government securities, the dominant asset or source component of the base. ${ }^{5}$ In recent decades changes in other sources either have been small or have been offset by changes in security holdings. A change in the Treasury's gold holdings is potentially an important source of increase or decrease in the base. However, since March 1968 the size of the gold stock has been changing only by small increments. In the postwar period the influence of changes in the gold stock were generally offset by compensating changes in Federal Reserve holdings of U.S. Government securities.

The liabilities or uses of the monetary base, or net monetary liabilities of the Federal Reserve and Treasury, are shown in Table $\mathrm{I}$ to be currency in circulation plus member bank deposits at the Federal Reserve. Part of the currency in circulation is held by the public, part is held as legal reserves by member banks, and another part is held as desired contingency reserves by nonmember commercial banks. In order to relate the uses of the base to the money stock, the uses are regrouped from the uses side of Table $I$ as

For a discussion of the statistical relation among source components of the base, see Michael W. Keran and Christopher Babb, "An Explanation of Federal Reserve Actions $(1933-68)$," this Review, July 1969.

$$
\begin{aligned}
\mathrm{R} & =\mathrm{RR}_{\mathrm{m}}+\mathrm{ER}_{\mathrm{m}}+\mathrm{VC}_{\mathrm{n}}, \\
\text { where } \mathrm{RR}_{\mathrm{m}} & =\text { required reserves of member banks, } \\
\mathrm{ER}_{\mathrm{m}} & =\text { excess reserves of member banks, } \\
\mathrm{VC}_{\mathrm{n}} & =\text { vatilt cash of nonmember banks. }
\end{aligned}
$$

In turn, required reserves of member banks are decomposed as:

$$
\begin{aligned}
\mathrm{RR}_{\mathrm{m}}= & \mathrm{R}^{\mathrm{d}}+\mathbf{R}^{\mathrm{t}}, \\
\text { where } \mathrm{R}^{\mathrm{d}}= & \begin{array}{l}
\text { required reserves behind demand de- } \\
\text { posits at member banks, }
\end{array} \\
\mathrm{R}^{\mathrm{t}}= & \begin{array}{l}
\text { required reserves behind time deposits } \\
\text { at member banks. }
\end{array}
\end{aligned}
$$

In turn, required reserves behind demand deposits at member banks are the sum of the amount of reserves required behind demand deposits over and under $\$ 5$ million at each reserve city and country

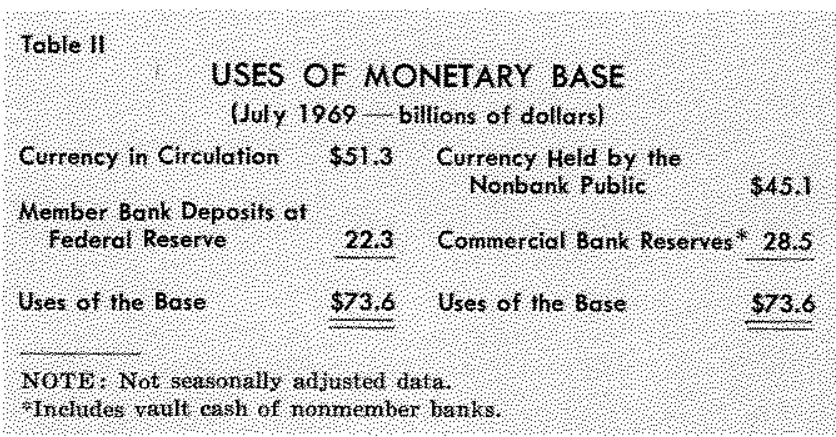




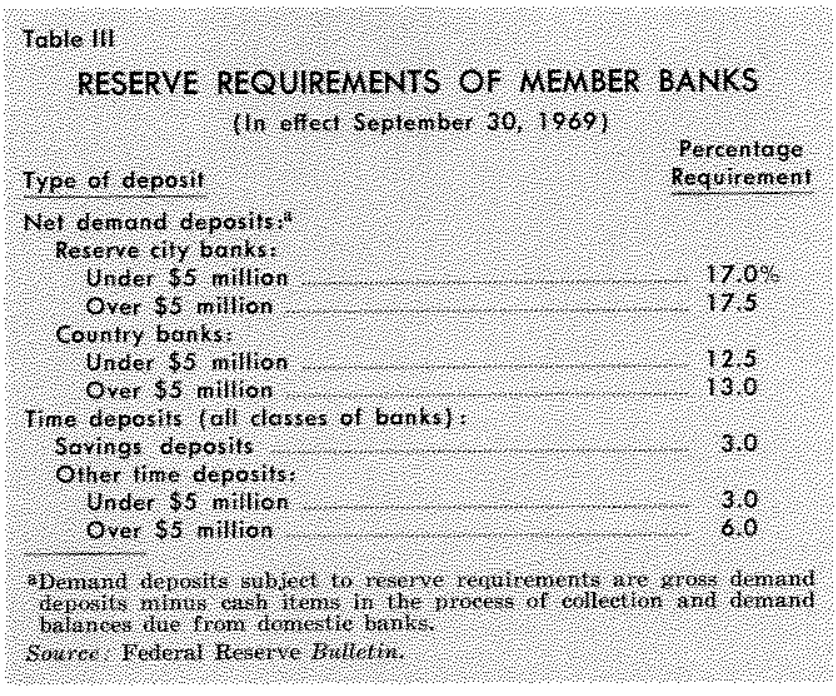

bank, and similarly for time and savings deposits." Present required reserve ratios for each deposit category are shown in Table III.

Alternatively, the total amount of commercial bank reserves can be expressed as a proportion ( $r$ ) of total bank deposits:

$$
\begin{aligned}
\mathrm{R}=\mathrm{r}(\mathrm{D}+\mathrm{T}+\mathrm{G}), \\
\text { where } \mathrm{D}=\text { private demand deposits } \\
\mathrm{T}=\text { time deposits } \\
\mathrm{G}=\text { U.S. Government (Treasury) deposits at } \\
\text { conmercial banks. }
\end{aligned}
$$

The "r-ratio" is defined to be a weighted-average reserve ratio against all bank deposits, but is computed directly by dividing total reserves by total deposits. ${ }^{7}$ The trend of the r-ratio in the postwar

6Expanding the equation for total bank reserves,

$$
\mathbf{R}=\mathrm{R}^{\mathrm{d}}+\mathrm{R}^{\mathrm{t}}+\mathrm{ER}_{\mathrm{mi} 1}+\mathrm{VC}_{\mathrm{H} 1}
$$

And since $\mathrm{R}^{\mathrm{d}}$, for instance, is the appropriate required reserve ratio times the amount of deposits in each reserve requirement classification, the above expression is rewritten in terms of weighted average reserve matios and deposits. See footnote No. 7 .

iFor the interested reader,

$$
\begin{aligned}
\mathrm{r}= & \mathrm{a} \delta \mathrm{r}^{\mathrm{d}}+(1-\mathrm{a}) \tau \mathrm{r}^{\mathrm{t}}+\mathrm{e}+\mathrm{v} \\
\text { where } \mathrm{a}= & \text { the proportion of member bank demand } \\
& \text { deposits to total deposits, } \\
\mathrm{\delta}= & \text { the proportion of net demand deposits } \\
& \text { of member banks to total demand de- } \\
& \text { posits, } \\
\mathrm{r}^{d}= & \text { a weighted-average reserve requirement } \\
& \text { ratio for member bank demand deposits, } \\
\tau= & \text { the proportion of net time deposits of } \\
& \text { member banks to total time deposits, } \\
\mathrm{r}^{\mathrm{t}}= & \text { a weighted average reserve requirement } \\
& \text { ratio for member bakk time deposits, } \\
\mathrm{e}= & \text { ratio of excess reserves to total batk } \\
& \text { deposits, }
\end{aligned}
$$

period is shown in Chart 11 on page 14. An important factor contributing to the gradual downward trend of the r-ratio is the relatively more rapid growth of time deposits (which are subject to lower reserve requirements) than demand deposits.

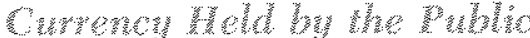

One of the important factors influencing the amount of money the banking system can create, given an increase in monetary base, is the proportion of currency to demand deposits the public desires to hold. For example, if the public held a fixed total amount of currency, all changes in the supply of base money by the Federal Reserve would remain in the banking system as reserves and would be reflected entirely in changes in deposits, the amount depending on the reserve requirement ratios for different classes and types of deposit. On the other hand, if the public always desired to hold a fixed ratio of currency to demand deposits (for example exactly $\$ .25$ in currency for every $\$ .75$ of demand deposits), the deposit creating potential of the banking system would be substantially less. Clearly the "currency drain" associated with an increase in the base must be taken into account in determining how much base money must be supplied to achieve a desired increase in the money stock. Currency (C) can be expressed as a proportion ( $k$ ) of demand deposits (D), that is:

$$
\begin{aligned}
& \mathrm{C}=\mathrm{k} \mathrm{D}, \\
& \mathrm{or} \\
& \mathrm{k}=\mathrm{C} / \mathrm{D} .
\end{aligned}
$$

Changes in the level of the "k-ratio" over time are influenced by such factors as income levels, utilization of credit cards, and uncertainties regarding general economic stability. The trend of the k-ratio is shown in Chart II. ${ }^{\mathrm{s}}$

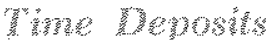

Time deposits are not included in the definition of the money stock discussed in this article. Nevertheless, since member banks are required to hold

$$
v=\text { ratio of nonmember bank vault cash to }
$$

This definition is altered somewhat by the recently instituted lagged-reserve-requirement provisions of the Federal Reserve. It is worth emphasizing that some of the above ratios are determined by the behavior of commercial banks and the public, and others are determined primarily by the Federal Reserve. The fact that these ratios are not fxed does not impair the usefulness of the analysis.

8For a detailed examination of the behavior of the currency to demand deposit ratio, see Phillip Cagan, Determinants and Effects of Changes in the U.S. Money Stock, 1875-1960 (New York: National Burean of Economic Research, 1965), chapter 4 . 


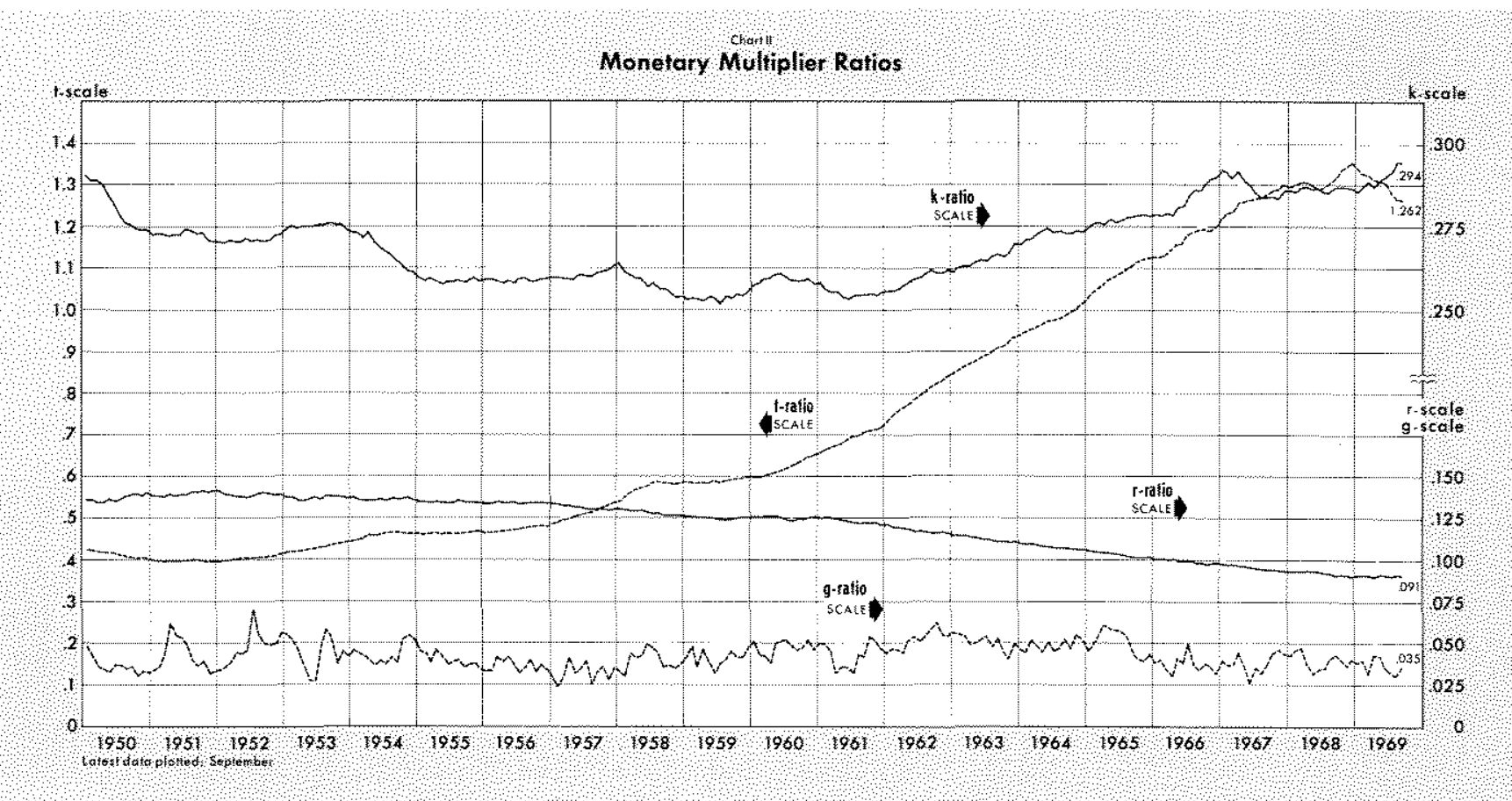

reserves behind time deposits, information regarding the public's desired holdings of time to demand deposits is necessary in order to determine how much the stock of money will change following a change in the stock of monetary base.

Reserve requirements are much lower against time deposits than against demand deposits as shown in Table III; consequently a given amount of reserves would allow more time deposits to be supported than demand deposits. Time deposits ( $\mathrm{T}$ ) can be expressed as a proportion ( $t$ ) of demand deposits (D), that is:

$$
\begin{aligned}
T & =t D \\
& \text { or } \\
t & =T / D
\end{aligned}
$$

The trend of the "t-ratio" is shown in Chart II.

The factors influencing the t-ratio are more complex to analyze than those affecting the k-ratio. Commercial banks are permitted to pay interest on time deposits up to ceiling rates set by the Federal Reserve and the Federal Deposit Insurance Corporation (see Table IV). Consequently, the growth of time deposits over time is influenced by competition among banks for individual and business savings within the limits permitted by the legal interest rate ceilings.

The interest rates which banks are willing to offer on time deposits (below the ceilings) are determined primarily by opportunties that are available for profitable investment of the funds in loans or securities.
Similarily, the decisions by individuals and businesses to deposit their funds in banks are influenced by the interest rates available from alternative earning assets such as savings and loan shares, mutual savings bank deposits, bonds, stocks, commercial paper, and direct

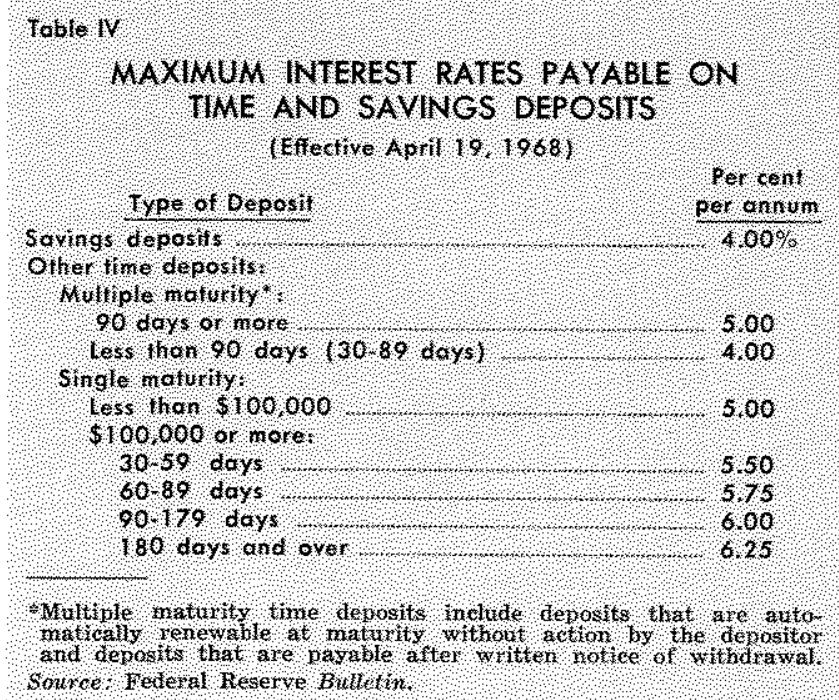

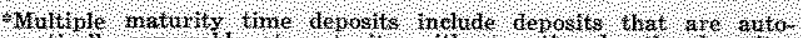
thetacally renewelle at maturits without action by the derositor. and depotits that are pasable after atitten hotice of tithirawal. Source tederal heserve Bullelin.

investments in real assets. ${ }^{9}$ If the interest returns from these other assets are sufficiently high that the interest rate ceilings on time deposits prevent banks from effectively competing for the public's savings,

9Jerry L. Jordan, The Market for Deposit-Type Financial Assets, Working Paper No. 8, Federal Reserve Bank of St. Louis, March 1969. 
then time deposits may not grow (or may even decline) and all increases in commercial bank reserves can be used to support demand deposits. This point will be discussed in more detail below.

\section{V.5. Gonernment Doposts}

Commercial banks are required to hold the same proportion of reserves against Federal Government demand deposits as against private demand deposits. Therefore, even though Government deposits are not included in the definition of the money stock, changes in the amount of Government deposits influence the amount of private deposits the banking system can support with a given amount of base money or reserves. Government deposits (G) can be expressed as a proportion ( $g$ ) of private demand deposits (D), that is:

$$
\begin{gathered}
G=g D, \\
\text { or } \\
g=G / D .
\end{gathered}
$$

The amount of Government deposits in commercial banks is determined by the flow of Treasury receipts (primarily from taxes) relative to Treasury expenditures, and by the Treasury's discretion about what proportion of its balances to keep with commercial banks rather than at the Federal Reserve. Thus, short-run fluctuations in the "g-ratio" are primarily the result of actions by the U.S. Treasury. The Federal Reserve must assess, from past experience and information available from the Treasury, what will happen to Treasury balances in an impending period in order to determine the influence of changes in Treasury balances on the money stock. The monthly pattern of the g-ratio is shown in Chart II.

\section{The Monetwe Multiplien}

All of the essential elements for determination of the money stock have now been discussed. The definitional relations are as follows:

$$
\begin{aligned}
& \text { (1) } \mathrm{M}=\mathrm{D}+\mathrm{C} \\
& \text { (2) } \mathrm{B}=\mathrm{R}+\mathrm{C} \\
& \text { (3) } \mathrm{R}=\mathrm{r}(\mathrm{D}+\mathrm{T}+\mathrm{C}) \\
& \text { (4) } \mathrm{C}=\mathrm{k} \mathrm{D} \\
& \text { (5) } \mathrm{T}=\mathrm{D} \\
& \text { (6) } \mathrm{C}=\mathrm{g} \mathrm{D}
\end{aligned}
$$

By substituting (3) and (4) into (2) we get:

$$
\text { (7) } \mathrm{B}=\mathrm{r}(\mathrm{D}+\mathrm{T}+\mathrm{G})+\mathrm{kD}
$$

that is, we express the monetary base solely in terms of the various deposits. Substituting (5) and (6) into (7), we get:

$$
\text { (8) } \mathrm{B}=\mathrm{r}(\mathrm{D}+t \mathrm{D}+\mathrm{g} \mathrm{D})+\mathrm{kD} \text {, }
$$

that is, we express the base solely in terms of private demand deposits to rednce the number of variables. Simplifying, we write (8) as:

$$
\text { (8) } \mathrm{B}=[\mathrm{r}(1+\mathrm{t}+\mathrm{g})+\mathrm{k}] \cdot \mathrm{D} \text {, }
$$

from which, by simple manipulation, we can express deposits in terms of the base as follows:

$$
\text { (9) } \mathrm{D}=\frac{1}{\mathrm{r}(\mathrm{l}+\mathrm{i}+\mathrm{g})+\mathrm{k}} \text { *B. }
$$

Since we want to find $D$ plus $C$, we use (4) and (9) to redefine $\mathrm{C}$ in terms of the base:

$$
\text { (10) } \mathrm{C}=\frac{\mathrm{k}}{r(1+t+g)+\mathrm{k}} \cdot \mathrm{B} \text {. }
$$

Substituting (9) and (10) into (1) gives:

$$
\text { (1) } \mathrm{M}=\frac{\mathrm{l}+\mathrm{k}}{\mathrm{r}(1+\mathrm{t}+\mathrm{g})+\mathrm{k}} \cdot \mathrm{B} \text {, }
$$

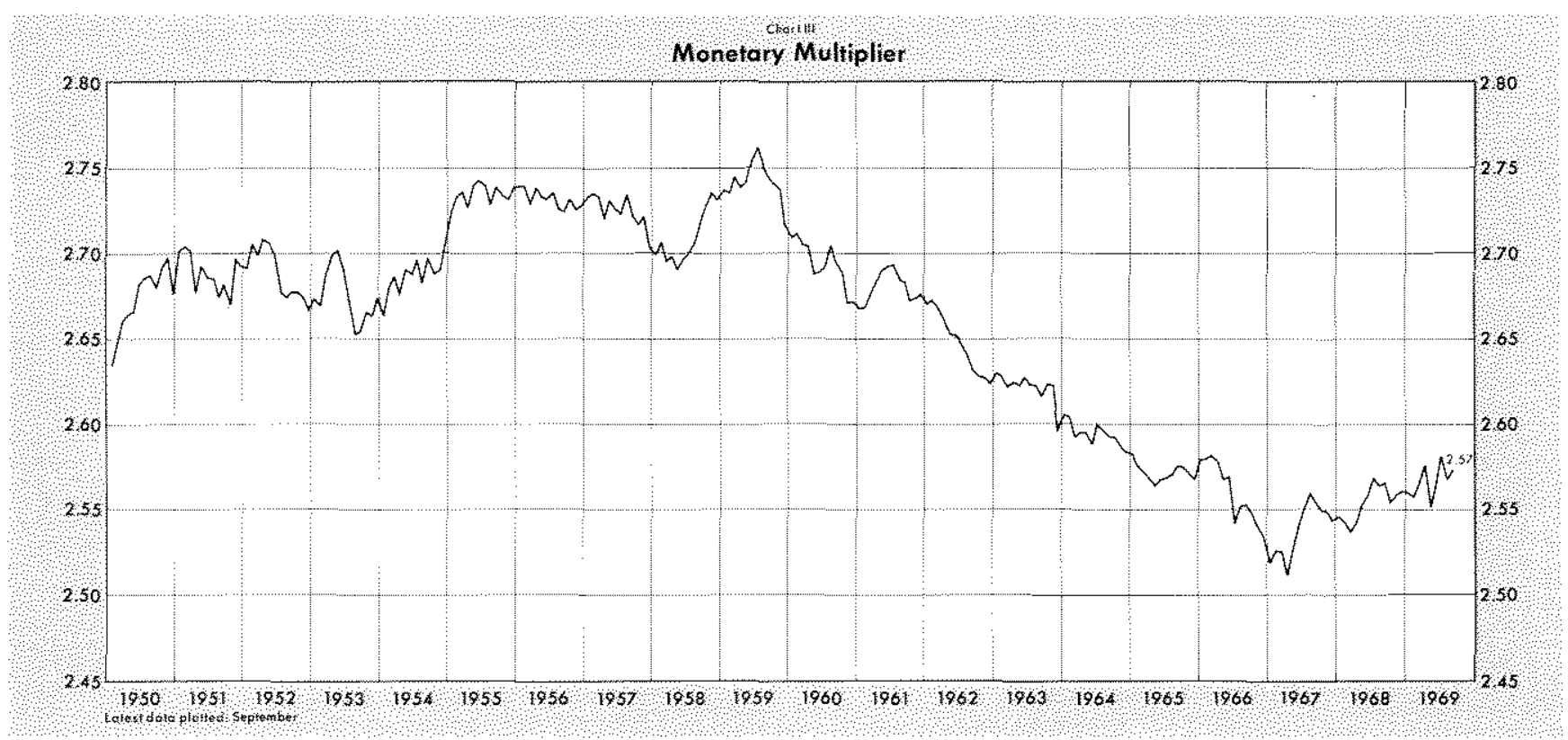

Page 15 
or the money stock defined in terms of the monetary base. ${ }^{10}$ We can denote the quotient as:

$$
m=\frac{1+k}{r(1+t+g)+k}
$$

where $\mathrm{m}$ is called the "monetary multiplier."11

The factors that can cause changes in the monetary multiplier are all of the factors which influence the currency ( $k$ ), time deposit ( $t)$, Government deposit $(\mathrm{g})$, and reserve ( $\mathrm{r}$ ) ratios, that is, the "behavioral parameters". The observed monthly values of these ratios in the past twenty years are shown in Chart II, and the monthly values for the monetary multiplier (m) are shown in Chart III. Quite obviously, if the monetary multiplier were perfectly constant, at say 2.5 , then every $\$ 1$ increase in the monetary base would result in a $\$ 2.50$ increase in the money stock. On the other hand, if the monetary multiplier were subject to substantial unpredictable variation, the Federal Reserve would have difficulty in determining the money stock by controlling the base.

Since the monetary multiplier is not constant, the Federal Reserve must predict the value of the multiplier for the impending month in order to know how much to increase the monetary base to achieve a desired level of the money stock. Techniques for predicting the monetary multiplier go beyond the scope of this paper. ${ }^{12}$ However, examples of how changes in time deposits and Government deposits influence the stock of money will be discussed.

\section{The Influence of Two Factors on the Money Stock}

The following sections present examples of the ways changes in the growth of time deposits and U.S. Government deposits influence the money creation process. The effects are illustrated both by changes in the ratios in the monetary multiplier and with the use of commercial bank balance sheet "T-Accounts."

10 Since the monetary base is adjusted for the effect of changes in reserve requirements, a corresponding adjustm ment is made to the reserve ratio( $r$ ).

11The reader should be able to demonstrate that if money is defined to include time deposits $\left(\mathrm{M}_{2}=\mathrm{D}+\mathrm{C}+\mathrm{T}\right)$, then

$$
m_{2}=\frac{1+k+t}{r(l+t+g)+k}
$$

12For one straight-forward approach, see Lyle Kalish, A Study of Money Stock Control, Working Paper No. 11, Federal Reserve Bank of St. Louis, July 1969.

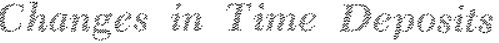

The growth of time deposits relative to demand deposits is determined by many factors, including those which influence the interest rates offered by commercial banks on such deposits and those which influence the quantity of time deposits demanded by the public at each interest rate. Both the banks'supply of time deposits and the public's demand for them are a function of relative costs and returns of alternative sources of funds and earning assets. Thus, accuracy of predictions of the tratio (time deposits to demand deposits) for a future perlod is influenced by the ability of the forecasters to anticipate the banks and public's behavior. Experience has shown that changes in this ratio tend to be dominated by rather long-run trends, with exceptions occurring at those times when interest rate ceilings imposed by the monetary authorities prevent banks from effectively competing for deposits. It is these special cases that will be discussed.

When market interest rates rise above the ceiling rates banks are permitted to offer on time deposits, some individuals and businesses who might otherwise hold time deposits decide to buy bonds or other

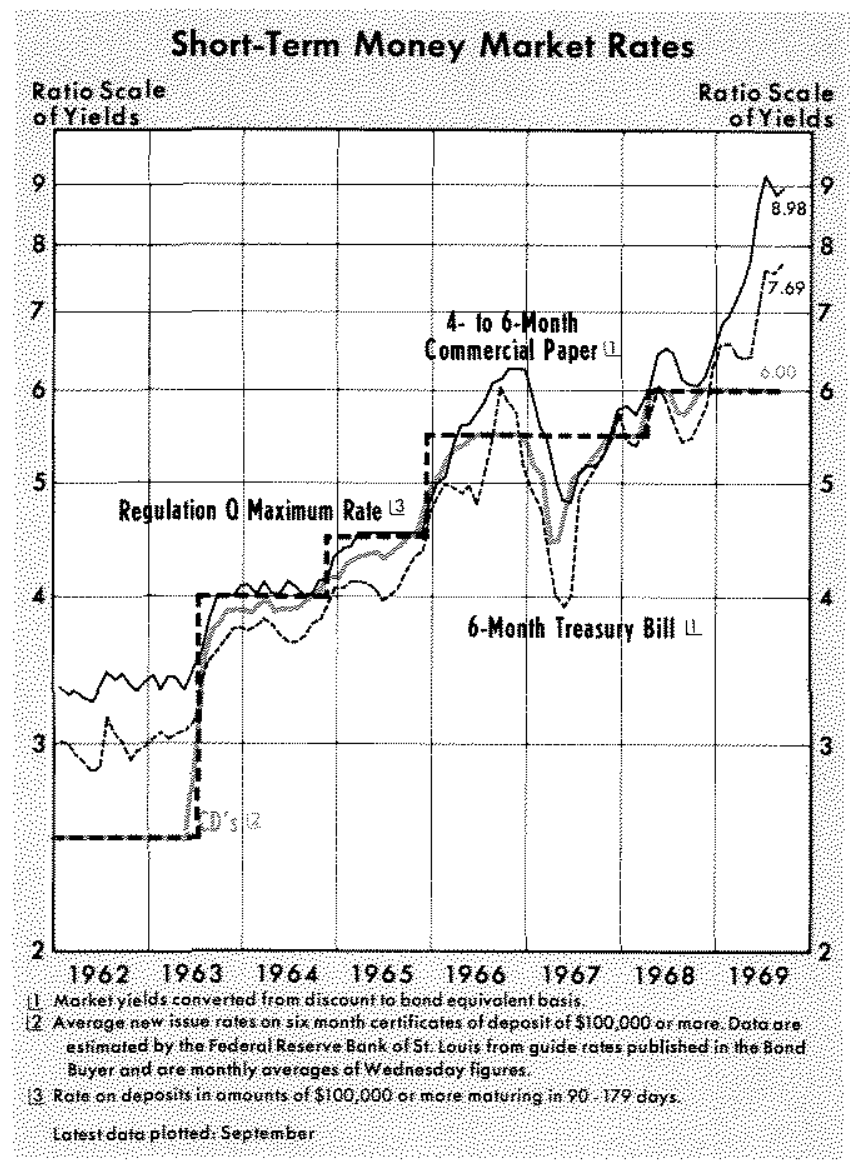


earning assets instead. This effect has been most pronounced on the banks' class of time deposits called "large negotiable certificates of deposit" (CD's). To depositors, these are highly liquid assets which are considered by the purchasers to be close substitutes for Treasury bills and commercial paper, ${ }^{13}$ On at least four occasions since 1965 the yields on these substitute assets have risen above the rates banks were permitted to offer on CD's, causing the growth of $C D$ 's to slow sharply or even become negative.

To illustrate the effect on the money stock of a rise in market interest rates above Regulation $Q$ ceilings, assume that the growth of time deposits ceases, and banks hold the same total amount of time deposits while demand deposits continue to grow. In the money supply model this is reflected in a decline in the t-ratio (time deposits divided by demand deposits), and since the t-ratio appears in the denominator of the multiplier, the multiplier would get larger as the t-ratio gets smaller.

For example, assume the following initial values for the monetary base and the parameters of the multiplier:

$$
\begin{aligned}
B & =\$ 75 \text { billion } \\
t & =1.3 \\
g & =.04 \\
k & =.3 \\
r & =.1 \\
\text { Since } M= & \frac{1+k}{r}(1+t+g)+k
\end{aligned}
$$

we can solve to find $M=\$ 182.6$ billion.

Now suppose that in the course of several months the base increases by $\$ 1$ billion, but time deposits do not grow at all as a result of the high market rates of interest relative to Regulation $Q$ ceilings. If all of the ratios in the multiplier (including the t-ratio) had remained unchanged in this period, the money stock would have increased by about $\$ 2.4$ billion to $\$ 185$ billion. But, since time deposits did not change while demand deposits continued to grow, the t-ratio would fall, to 1.28 for example, which causes the multiplier to increase (still assuming the other behavioral parameters remain the same), ${ }^{14}$

The reader should be careful not to interpret this greater increase in money (especially demand de. posits) to mean that the banks can extend more

\footnotetext{
13Jordan, Deposit-Type Financial Assefs, chapter 4.

14In practice, as the t-ratio falls from 1.3 to 1.28 , demand deposits grow and time deposits do not, and the average reserve requirement ratio (r) will rise. This will slightly attenuate the increase in the multiplier and the money stock.
}

credit than otherwise. Since the reserve requirements on demand deposits are greater than on time deposits, the $\$ 1$ billion increase in monetary base would have supported a greater amount of total deposits (demand plus time) if time deposits grew proportionally to demand deposits, rather than only demand deposits increasing. With the assumed initial values for the parameters of the multiplier and the postulated $\$ 1$ billion increase in the monetary base, money plus time deposits would have increased by almost $\$ 4.8$ billion, almost twice as much as money.

To interpret the effects of this increase in money on the cconomy, it is necessary to analyze the increase in the supply of money compared to the demand for money to hold, and the supplies of and demands for other assets. We postulated above that market interest rates rose above the ceiling rates banks are permitted to pay on time deposits (expecially CD's). In such a situation the volume of CD's (quantity supplied) is any amount depositors wish at the ceiling rates. Since the yields on good substitutes become more attractive than CD's, the demand for CD's declines, resulting in a decline in the outstanding volume of CD's or a slowing in the growth rate. In other words, a change in the relative yields on substitute assets causes a shift in the demand for CD's (negative), which causes a decline in the volume.

\section{Disingermediation}

We noted above that total deposits of banks may decline as a result of this "disintermediation" of time deposits. This means that banks must contract their assets, either loans or security holdings, as deposits decline. An understanding of the actions of banks in the face of a deposit drain and actions of those who withdraw their deposits is important information in assessing the effects of the disintermediation caused by the interest rate ceilings.

To illustrate two possible effects of disintermediation, we will use highly simplified examples and Taccounts (commercial bank balance sheets). Account I shows the banking system in its initial condition having total reserves (TR) $=\$ 25$, required reserves $(\mathrm{RR})=\$ 25$ and excess reserves $(\mathrm{ER})=0$, security holds (S) $=\$ 100$ and loans outstanding (L) $=\$ 175$. Bank liabilities are demand deposits (DD) $=\$ 100$ and time deposits (TD) $=\$ 200$. We have assumed that reserve requirements against demand deposits are 15 per cent and reserve requirements against time deposits are 5 per cent. 


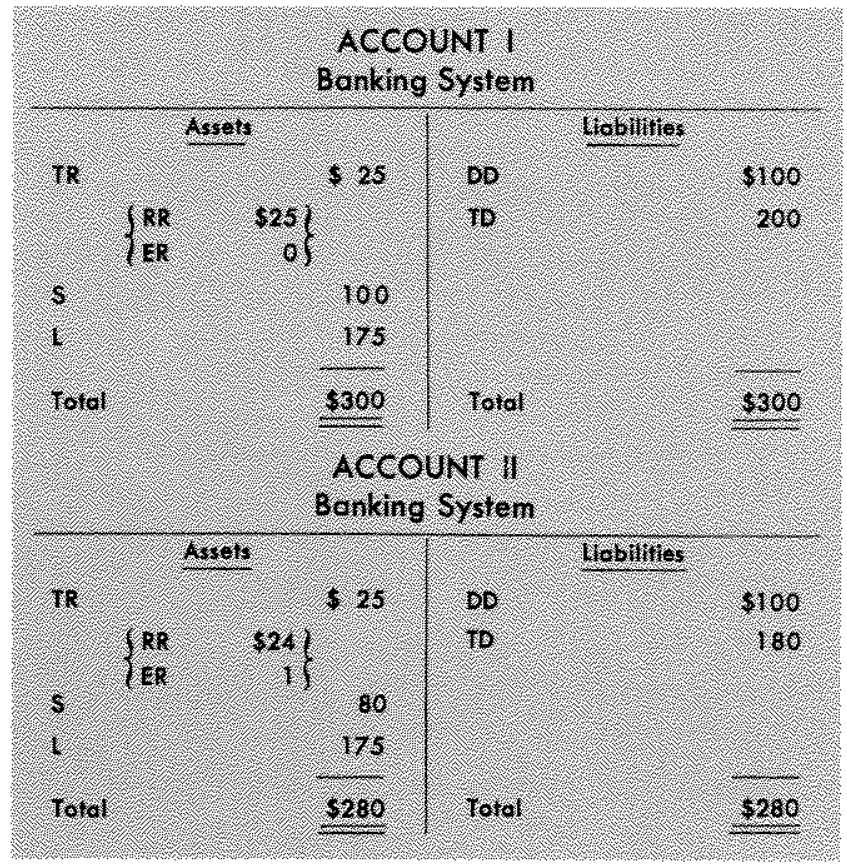

Account II shows the effect of a corporation reducing its holdings of time deposits by $\$ 20$ and buying $\$ 20$ in securities from the banks, because of the higher return available on the latter. The immediate effect is that the ownership of the securities is changed - the corporation directly holds the securities instead of having a deposit in a bank which owns the securities, hence the term "disintermediation" - and the banks are left with $\$ 1$ of excess reserves. The banking system can create loans (or buy some securities), based on the dollar of excess reserves, and increase demand deposits by a multiple of $\$ 1$. In this simplified example, the effect of disintermediation resulting from relatively low interest rate ceilings is potentially expansionary on total loans, even though total deposits decrease.

For the second example, a bank, in its usual role as an intermediary, sells CD's to a corporation which wishes to invest short-term funds. With the proceeds of the sale of the CD's, the bank lends to another corporation (less the amount the bank must hold as required reserves, of course). Another simplified example of the potential effects of disintermediation on the banking system and total credit is illustrated in Account III. For exposition, assume that the onebank holding companies of commercial banks establish subsidiaries for the purpose of buying and selling commercial paper.

For our example, assume the first corporation does not wish to renew $\$ 20$ of its CD holdings when they reach maturity, but rather, because of generally rising short-term market interest rates, seeks a yield

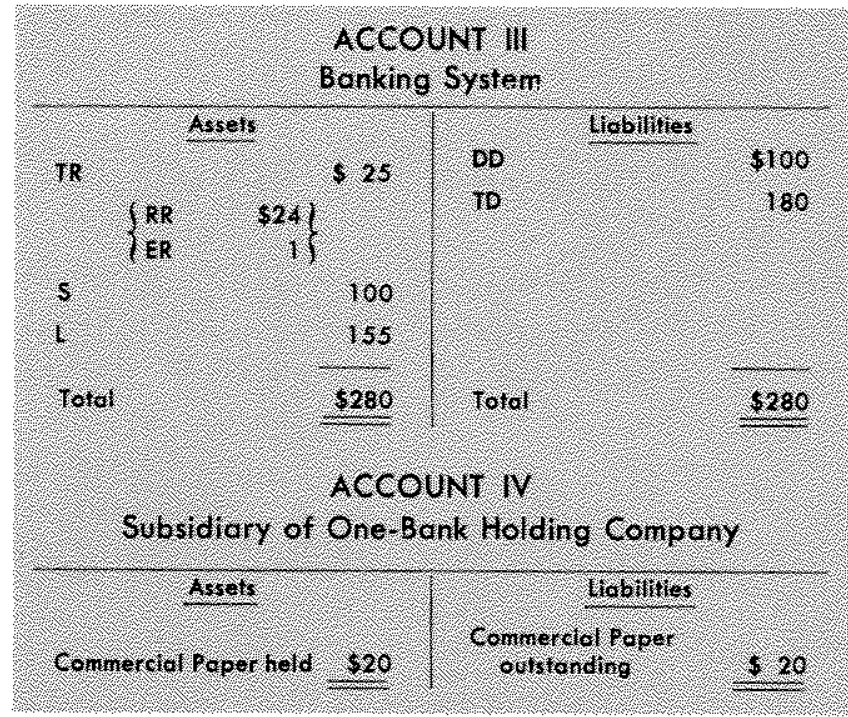

greater than the bank is permitted to pay. Our hypothetical subsidiary of the one-bank holding company can offer to sell its own commercial paper (1.O.U.) to the first corporation at competitive market interest rates (Account IV).

We assume the corporation buys the subsidiary's commercial paper. As a result of their reduced deposits the banks are forced to contract assets proportionately (as a first step in a partial analysis). Instead of selling securities, as in our previous example, the banks can contract loans outstanding by $\$ 20$, as shown in Account III (as compared to Account I). The subsidiary can in turn use the proceeds of its sale of commercial paper to purchase the paper of another corporation which seeks to borrow short-term money, possibly a corporation which was having difficulty getting a bank loan since bank assets and liabilities were contracting.

We find that the initial effect of the disintermediation is that the total of bank loans plus commercial paper debts of borrowing corporations is the same as the initial amount of bank loans outstanding, and that the total of time deposits plus commercial paper assets of lending corporations is the same as the initial amount of time deposits at banks. However, we also find that banks have acquired an additional $\$ 1$ of excess reserves which they can lend and thereby increase demand deposits.

In summary, both of the examples of the disintermediation of time deposits caused by the interest rate ceilings show that the same initial amount of reserves in the banking system can, under certain circumstances, support a larger amount of demand deposits (and therefore money stock). In other 
words, if the disintermediation means only that some funds flow through channels which are not subject to reserve requirements and interest rate ceilings, the effects of the relatively low interest rate ceilings on commercial bank time deposits are potentially expansionary on total loans.

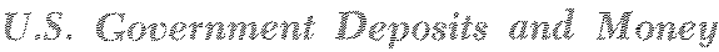

As previously discussed, the monetary base summarizes all of the actions of the Federal Reserve which influence the money stock. However, the Treasury cannot be overlooked as an agency which can influence the money stock over at least short periods. In the money supply model, the influence of changes in the amount of Government deposits is reflected in movements in the g-ratio (Government deposits divided by private demand deposits) in the monetary multiplier.

In recent years the Government's balances at commercial banks have fluctuated from $\$ 3$ billion to $\$ 9$ billion within a few months time. Private demand deposits averaged about $\$ 150$ billion in mid- 1969 . The g-ratio is therefore quite small, ranging from about .02 to about .06 , but frequently doubles or falls by half over the course of a month or two.

Similar to the effect of changes in the t-ratio, in creases in the g-ratio result in a fall in the multiplier since the ratio appears in the denominator. Using again the initial values we assumed for the base and multiplier, we have:

$$
\mathrm{M}=\frac{1+.3}{.1(1+1.3+.04)+.3} \cdot \$ 75 \text { billion }=\$ 182.6 \text { billion }
$$

where .04 is the value of the g-ratio. These values imply that demand deposits (D) are about $\$ 140.5$ billion and Government deposits $(\mathrm{G})$ are $\$ 5.6$ billion. Now suppose that individuals and businesses pay taxes of $\$ 1$ billion by writing checks which draw down (D) to $\$ 139.5$ billion, and Government balances rise to $\$ 6.6$ billion. Assuming no change in time deposits or currency held by the public and no change in the base, we would find that the g-ratio rises to .047 (and the k- and t-ratios rise slightly) to give us:

$M=\frac{1+.302}{.1(1+1.309+.047)+.302} \cdot \$ 75$ billion $=\$ 181.6$ billion

A similar example of the effects on the money stock of an increase in Government deposits at commercial banks which is associated with a change in time deposits (people pay taxes by reducing their savings or holdings of CD's) would be somewhat more complicated. In the above example, taxes were paid out of demand deposits, and the reserve ratio (r) was not changed, which implies that the distribution of the increment in Government deposits among reserve city, country and nonmember banks was the same as the distribution of the $\$ 1$ billion reduction in private demand deposits.

When taxes are paid out of time deposits, the $\mathrm{r}$ ratio rises, since reserve requirements against Government deposits are approximately three times the reserve requirements against time deposits. These movements are very small, and any accompanying reduction in the excess reserve ratio would attenuate the effect. Nonetheless, the effect on money is a combination of small changes in the k-, r-, t-, and g-ratios.

\section{Summary}

The behavioral parameters of the money supply framework presented here are the currency $(k)$, reserve ( $r$ ), time deposit ( $t$ ), and Government deposit (g) ratios. The changes in these ratios reflect the actions of the Treasury, banks, and nonbank public which infuence the money stock. The k-ratio is determined by the public's preferences for currency versus demand deposits; the t-ratio reflects the interaction of the banks' supply of and the public's demand for time deposits as compared to the supply of and demand for demand deposits; and the g-ratio is dominated by changes in Government balances at commercial banks. The r-ratio is the least volatile of the behavioral parameters, although it is influenced by the banks' desired holdings of excess reserves and the distribution of total deposits among all the subclasses of deposits in the various classes of banks, which are subject to a large array of reserve requirements.

The main policy actions of the monetary authorities - open market operations, changes in reserve requirements, and administration of the discount window - are summarized by the monetary base. The growth of the base summarizes the influence of the monetary authorities' defensive and dynamic actions on the growth of the money stock, regardless of the intent of these actions. The degree of accuracy that can be achieved by the monetary authorities in controlling the money stock is a function of their ability to determine the monetary base, and to predict the net influence of the public's and banks' behavior as summarized by changes in the money supply multiplier.

This article is available as Reprint No. 46. 